MarkETING AND BRANDING
RESEARCH $\begin{gathered}\text { INDUSTRIAL } \\ \text { MANAGEMENT } \\ \text { INSTITUTE }\end{gathered}$

\title{
Impact of technology and equipment equity on price levels of products
}

\author{
Yordan Hristov Ivanov*, Darina Pavlova Pavlova \\ University of Economics-Varna, Varna, Bulgaria
}

\begin{abstract}
Keywords: Customer Equity, Perceived Value, Pricing

Correspondence: jordan.ivanov@uevarna.bg

The dynamics of contemporary economic processes urge researchers in the marketing field to study pricing outside of its traditional role. Modern customer-oriented approaches examine price levels as an instrument which contributes to retention and attraction of clients. Retention and expansion of client base is a subject-matter of the concept of customer equity which aims at long-term enhancement of customer relationship value. This value depends directly on the price levels defined by business organizations. Therefore, excessive application of discounts and sales may be risky for the company as it may turn its clients into "discount hunters" which will have detrimental impact on customer equity. In this regard, the current study aims to discover opportunities to enhance price competitiveness through promotion of customer perceived value. In pursuance of the objective of the present study, the drivers influencing the perceived value and particularly the technology and equipment equity were examined. As a result, the content of the factor was clarified and its positive impact on the level of customer perceived value was established. Guidelines were established for building technology and equipment equity, enhancement of the perceived value of products, and price competitiveness.
\end{abstract}

\section{Introduction}

Recent observations in the field of entrepreneurship show that successful examples of business management demonstrate a tendency for a product-to-consumer shift in the focus. This tendency is based on the paradox that while consumers have a growing number of choices, their satisfaction tends to decrease. Consequently, top managers have more strategic options but gain less profit. The solution to this problem is based on the application of some modern customer-oriented concepts such as consumer relationship management, customer 
lifetime value, and customer equity. They offer possibilities for maintenance and expansion of the client base and at the same time address the issues of maintaining relationships with the customers that are profitable for the company. It is true that the value generated from these relationships depends on the price determined by the company. Thus, the decisions related to price levels are of essential importance to the business organization since on the one hand, they reflect directly company profits, and on the other hand, they have an impact on consumer choice and customer retention. To address these issues, the current article focuses on the concept of Customer Equity which distinguishes the creation of value for customers as an opportunity to increase the perceived value of products. Such an increase provides freedom to managers to determine competitive prices of their products which generate profit for the business organization.

The aim of this article is to outline the possibilities of price-increasing competition through fostering of perceived value for customers. Therefore, the article examines the relationship between Technology and Equipment Equity for consumers as a driver of customer equity and price levels of products. The study was carried out on the Bulgarian Craft beer market and the choice of studying Technology and Equipment Equity is justified by the growing interest of consumers in production methods, which has encouraged some businesses to communicate these methods to the general public.

\section{The Literature Review}

\section{Theoretical Basis for the Relation "Technology and equipment equity" - "Perceived Value" - "Price Level"}

Contemporary concepts based on the understanding of value creation for all market participants quickly gain force and go beyond the traditional approaches for relationship management. In this regard, the concept of customer equity presents significant opportunities for studying the behavior of current company customers with an aim to prolong companyclient relationships and generate value in the long term. As a result of the studies of numerous researchers (Blattberg \& Deighton, 1996; Blattberg, Getz, \& Thomas, 2001; Hanssens, Rust, \& Srivastava, 2009; Leone et al., 2006; Rust, Lemon, \& Zeithaml, 2004; Vogel, Evanschitzky, Ramaseshan, 2008), the definition of the concept of customer equity has been generally adopted. Based on these theoretical achievements, Pavlova (2015) summarizes that customer equity is the value expression of current and future relationships with the actual clients of the business organization through which tangible and intangible profits for the company are generated. This definition determines the necessity of customer equity management on part of the organization as long as the clients are its main source of profit.

The concept is based on the notion that the customer is a strategic resource and generating value, which has to be calculated, managed, and maximized (Blattberg e al., 2001). The magnitude of this value depends on the price decisions about the company's products, as long as the consumer choice largely depends on price levels. To this end, this is the reason which gives rise to interests about studying the possibilities to increase price competitiveness. The review of relevant researches in the field gives us a basis to claim that there are two main approaches for customer equity management. Based on their content, they are defined as a process approach (Blattberg et al., 2001) and value based approach (Lemon, Rust, Zeithaml, 
2001; Leone et al., 2006). For the purposes of this article, the objective has been to review the value based approach.

This approach puts a focus on the customer lifetime value and suggests possibilities for its extension. The authors examine customer equity management through the analysis of customer behavior and the definition of the drivers that influence customers to buy from a specific company now, as well as in the future (Lemon et al., 2001; Leone et al., 2006; Rust, et al., 2004). This approach is based on the analysis of the three stages of relationship between the company and its consumers. The first stage examines customer acquisition. At this stage, the client already has a certain attitude towards the brand and the product before he/she has made a purchase. Based on this attitude, during the second stage and after the purchase, the client evaluates the brand equity and value equity. As a result of these evaluations, the customer continues to buy the same company's products. During the third stage, the existing relationship between the company and the customer is analyzed and with the help of specific marketing instruments this relationship is further developed into relationship equity for the client. Therefore, the authors distinguish three drivers that have an impact on the long-term value of the relationship with the client. According to the value based approach, the business organization can maintain and expand its client base by forming value equity, brand equity, and relationship equity for the consumer (Lemon et al., 2001). Hence, customer equity depends on the impact of these three drivers (Rust et al., 2004).

Based on the analysis of the notions of customer equity management and the application of the value based approach, Pavlova (2016) highlights the possibility for identifying the fourth driver. According to Pavlova (2016), in the current market environment, apart from the above mentioned developments, production companies also compete in the implementation of modern equipment and technology. Production technology consists of the combination of methods and instruments used for achieving a desired outcome. It encompasses the sequence of operations and procedures and is directly related to the using of machines, equipment, instruments, materials, and the ways to combine them. In the marketing context, the contemporary technological environment is dynamic and business companies aim at involving their clients into the production process and at making them aware of this. In addition, companies often use technology as a way to distinguish themselves from other producers. Production companies often inform their costumers about innovations applied to their production process, using appropriate visualization to maintain a relationship of trust with their clients and to form positive attitudes towards their activity, product, and brand. Likewise, the quality and origin of the raw materials and ingredients used in the production process are also shown in a similar manner. Based on the presented research, the impact of the implemented technology and equipment on consumer behavior has been identified as the fourth driver which determines customer equity of industrial enterprises - Technology and Equipment Equity. The correlation between technology and equipment equity and customer equity was empirically tested (Pavlova, 2016). The term Technology and Customer Equity is defined as the consumer evaluation of the technology and equipment implemented in the company production process.

Therefore, a new set of values has been formed in determining the key drivers in customer equity management in relation to industrial enterprises and their products. The focus of the 
current research is Technology and Equipment Equity for clients and the possibilities for its formation, which in our opinion is under-researched, but of growing importance to companies. Figure 1 shows the customer equity drivers.

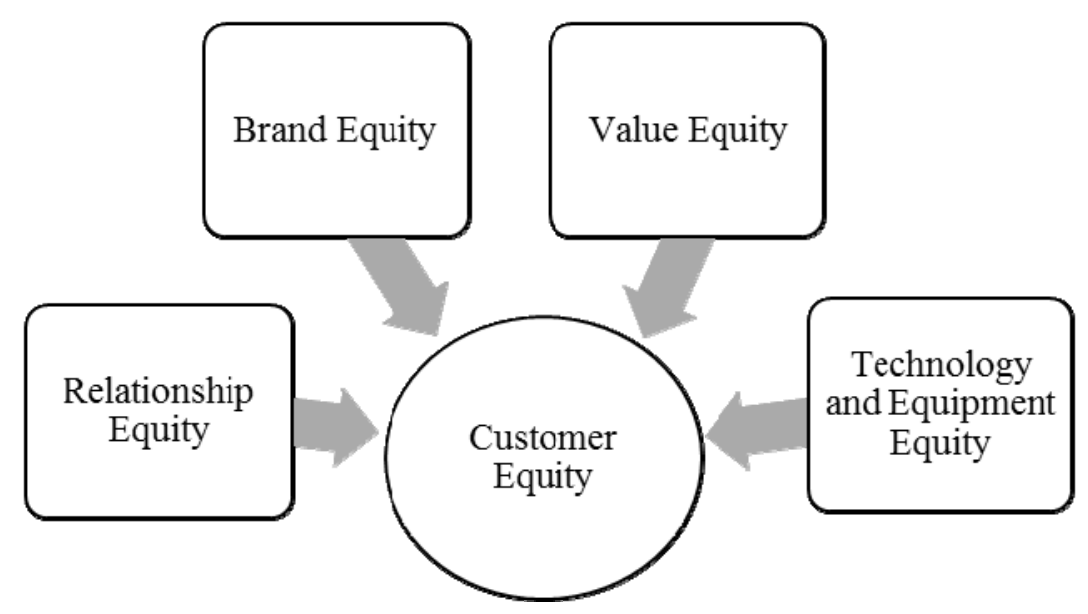

Figure1. Customer equity drivers (Pavlova, 2016)

Based on the presented viewpoints of customer equity and the drivers for its management, it can be deduced that there is a direct link to the concepts of consumer value and value for consumer. That is due to the fact that customer equity management aims at forming value for the consumer which in return, generates value for the company in the form of revenue.

Value for customer can be determined as the complex satisfaction from the acquiring and using a product which is often related to product value (Nagle, Hogan, \& Zale, 2011). It is divided into objective and perceived value (Ivanov, 2016). Objective value is the combination of all benefits submitted to the client by the available product on the market regardless of whether the consumer deems them as useful or not. Some of the attributes of this value are quality improvement, speed of service, warranty extension, order, and delivery service improvements, accessible locations, and many others. Perceived value, on the other hand, includes only the realized benefits that the consumer believes the product actually provides (Ivanov, 2016). The significance of this value confirms the words of Kotler (2005) that value depends on the perceiving side.

The institute for marketing research included the definition of perceived value in its list of research priorities for 2006-2008. These studies generated high interest, based on the phenomenon of value creation, advocated in the marketing research on part of the business and academic communities (Sánchez-Fernández \& Iniesta-Bonillo, 2007). Various definitions of perceived value exist in the marketing literature (Holbrook, 1999; Woodruff, 1997; Zeithaml, 1988). The most popular definition belongs to Zeithaml (1988) who stated that perceived value refers to the consumer's general evaluation of the practicality of a product based on realizations of what is received and what is given. This opinion defines perceived value as a one-dimensional structure which can be measured only by interviewing consumers about what they have gained from each of their purchases (Sánchez-Fernández \& IniestaBonillo, 2007). 
Based on the information stated above, the study claims that objective value has economic outcome and perceived value - psychological outcome. Actually, the maximum price that the customer is willing to pay for a specific product or service depends on perceived value. According to Baker (2006) business determines the value it creates for its clients and price speaks for the value offer of the business company more than any other component of the marketing mix; following this, it serves as a confirmation of the existing link between price and value. Therefore, it can be concluded that perceived value has a significant impact on the pricing of products and services as it can be viewed as a price cap. Consequently, increase of perceived value for clients is of key importance. Thus, the effect of conducting one or another targeted price policy on part of business organizations can be modeled through targeted actions for management of key drivers and, more specifically, technology and equipment equity for consumers. To this end, Furtwengler (2010) stated that the actual reason that business owners do not support price rising is that they do not know how to turn value into money. Furtwengler (2010) also presented that managers do not know how to define value in a quantifiable way.

It is believed that the marketing efforts of business organizations must be oriented towards the creation, formation, and maintenance of value in all of its forms. The analyses related to the value and flexibility of the competitive price policy of businesses must address and abide by the processes of formation of value creation in two main aspects, namely resource and marketing. The development of the theory of "value" and, more specifically, of its cocreation leads to the conclusion that customers would care less about expenses or the actual price they pay and would consider the concept of "purchase stimulus" more than anything else. As M. H. Morris and G. Morris (1990) stated, the price should reflect value and not expenses.

The formation of technology and equipment equity in production adds tangible and intangible benefits for the consumers which increases their satisfaction. Therefore, the current study is directed at finding opportunities for growth of price levels competitiveness through examining the impact of this driver.

In conclusion, by subjecting the economic relationship between the value approach and the customer-oriented approach, the efforts of the production companies must be directed at the increase of perceived value as a direct result of "conscious need". Similar realization is also observed in relation to technology and equipment equity. Thus, the study examines the impact of this value on perceived value and price levels of products.

\section{Method}

\section{Research Design}

In pursuance of the objective of the present study, a research was conducted which presents the relationship between the constructs of technology and equipment equity and perceived value for customers. The presented relation is assumed to be significant to a production company regardless of the nature of its activity. The empirical testing of the presented relation also requires a selection of a product category.

The activity of "micro" and "small" industrial enterprises in class C.11.05 "Brewery" in Bulgaria was examined. Despite the competitive pressure of the leaders in this sector, they 
successfully adapt to conditions and manage to maintain their position on the market by attracting more and more real consumers. In search for advantages, these breweries are forced to offer their customers a unique product to justify its higher price. This is why in recent years there has been a growing interest in the so called "Craft Beer." According to the Bulgarian Association of Home Brewers established in 2013, craft beer is produced by small, often family-owned breweries, producing original, special beers of high quality and traditions that are interesting to the consumer. Defined within these parameters, craft beer maintains an arsenal of features through which, based on the unique qualities of the product, it justifies the competitiveness of the price of that product. One of these features is the formation of technology and equipment equity for craft beer consumers. It is for those specific reasons that the current research has chosen the Bulgarian craft beer market for its study.

Based on the provided theoretical data and the product category of choice, a conceptual model of the research was developed (Figure 2). The illustrated model reflects the positive impact of the applied technology and equipment equity value on the perceived value of craft beer consumers. The conclusion is that the bigger the range between the cost and the perceived value of the product is, the more flexible the producing company in determining the product price would be. Therefore, even more expensive products are still preferable and competitive when there is a significant positive difference between perceived value and market price.

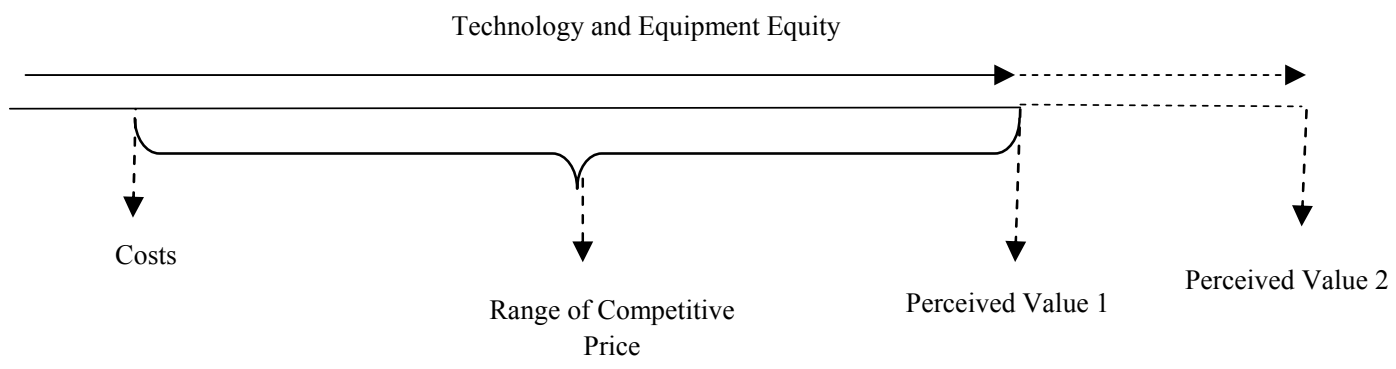

Figure 2. Conceptual model of the research

The methodology of the current study was designed based on the working conceptual model. In order to identify the variables which form technology and equipment equity for craft beer consumers and its impact on perceived value, it was decided to conduct exploratory and basic investigation. The research design consisted of the following stages including the exploratory program that was designed based on four basic steps; selection of a product category for the purposes of the research - craft beer was considered; following this, the establishment of a research hypothesis, namely technology and equipment equity for craft beer consumers which positively impacts perceived value was taken into account; and the inquiry of craft beer consumers was implemented to refine the variables forming the driver value of technology and equipment equity.

A group of 15 regular craft beer consumers was formed which were tasked to describe those aspects of craft beer related to its production that were significant to them. As a result, a series of indicators including raw materials, origin, type of brewery, alcohol percentage, taste, 
and content, production technology for technology, and equipment equity were identified. The identified indicators forming value for consumers were established as the variables forming technology and equipment equity. The significance of some of these variables is supported by the marketing literature but the impact of all variables was tested during the course of the basic research study.

\section{Procedures}

The study included craft beer consumers in Bulgaria. The first step in the course of the basic research investigation was to collect data related to the basic constructs presented in the conceptual model, namely technology and equipment equity and perceived value of craft beer for consumers. For this purpose, a one-time enquiry to the consumers was executed by means of a designed electronic questionnaire consisting of measurements for each of the components of the conceptual model. It was distributed via various electronic pages which made it accessible to a high number of people. The size of the convenience sample is 136 consumers.

\section{Measurements}

The testing of the presented research model was implemented by means of measurements designed specifically for this purpose. As a result of a thorough review of the customer equity and perceived value research, a questionnaire was designed which consisted of three sections of questions.

The first section consisted of general questions: A control question, which aims to filter the respondents and those of them who consume craft beer, followed by two questions related to the average price which consumers pay most often for a bottle $(500 \mathrm{ml})$ of craft beer and the average monthly consumption of the product.

The second set of questions consisted of 11 items measuring technology and equipment equity for consumers and one open question to determine the price cap of craft beer for the respondents (perceived value).

Technology and equipment equity is a construct consisting of numerous variables which orders its measurement by means of designing a scale for each of the consisting variables. This approach for studying such complex constructs is called a multi-dimensional approach and is implemented by various researchers in the field (O'Cass, 2001; Prendergast \& Wong, 2003; Vogel et al., 2008). Measuring scales were designed for client attitudes towards the craft beer they consume in the formation of technology and equipment equity. For this purpose, statements consisting the basic principles and determining consumer choice of craft beer were presented by means of the Likert scale with five options: 1) strongly disagree, 2) somewhat disagree, 3) undecided, 4) somewhat agree, and 5) completely agree, by the example of Dodds, Monroe, and Grewal (1991). Eleven variables were determined as a result of an interview with a focus group conducted at an earlier stage of the research study.

Perceived value for customers, on the other hand, allows for the application of onedimensional and multi-dimensional approach. The first approach conceives perceived value as a one-dimensional construct. Regarding this view, perceived value is considered as a single overall concept that can be measured by a self-reported item that assesses the 
consumer's perception of value (e.g. Agarwal \& Teas, 2002; Brady \& Robertson, 1999; Chang \& Wildt, 1994; Dodds et al., 1991; Hartline \& Jones, 1996; Kerin, Jain, \& Howard, 1992; Sweeney, Soutar, \& Johnson, 1999). The second approach consider perceived value as a multi-dimensional construct that comprises of various interrelated attributes or elements that shape a holistic representation of a complex phenomenon (e.g. Babin, Darden, \& Griffin, 1994; Holbrook, 1994; Huber, Herrmann, \& Braunstein, 2000; Mattsson, 1991; Sheth, Newman, \& Gross, 1991; Sweeney \& Soutar, 2001; Williams \& Soutar, 2000). For the purposes of the current research study, the one-dimensional approach of Zeithmal (1988) was adopted. According to this approach, perceived value is determined by the judgment of the consumer of what he/she would give for the benefit that the product offers. Therefore, a scale which measures the perceived monetary value of craft beer for consumers was designed.

The third set of questions comprised of demographic questions about the sex/gender, income, and age of the respondents. For the purpose of the basic research study, the data analysis was conducted by means of parametric tests. In testing the presented research hypothesis, a one-way analysis of variance was applied (ANOVA). The conduction of all preliminary checks on compliance with the basic requirements for the application of the relevant analyzes is envisaged.

\section{Results}

The electronic questionnaire was completed by 204 respondents. After eliminating the questionnaire cards of those who replied negatively to the control question about the consummation of craft beer, the full sample consisted of 136 respondents, comprised of 104 (76.5\%) male respondents and 32 (23.5\%) female respondents.

An analysis of the sample was conducted based on other demographic characteristics as well. In relation to the structure of the sample, based on the monthly income of the respondents, it consisted of $8.8 \%$ of the respondents, having monthly income of up to 500 BGN; $38.2 \%$ of the respondents with monthly income between 501 and 1500 BGN; 36.76\% of the respondents with monthly income between 1501 and 2000 BGN; and $16.24 \%$ of the respondents with monthly income over $2000 \mathrm{BGN}$.

The distribution of the sample based on the age of the respondents was as follows: $28.68 \%$ of the respondents were between 18 and 30 years of age; $55.88 \%$ of the respondents were between 31 and 40 years of age; $8.82 \%$ of the respondents were between 41 and 50 years of age; $6.62 \%$ of the respondents were over 50 years of age.

The data related to the consummation of craft beer were as follows: $33.82 \%$ of the respondents buy up to 5 bottles monthly; $14.71 \%$ of the respondents buy between 6 and 10 bottles monthly; $51.47 \%$ of the respondents buy over 10 bottles per month.

The reliability of the designed measurements was tested using the Cronbach's Alpha factor. The factor value warranted the claim that the construct technology and equipment equity was highly reliable as it registered value of 0.827 and exceeded the required value of 0.6 (Nunnally, 1967). Based on the data obtained, the measurements proved to be reliable, meaning that their application for the purpose of conducting the basic research was justified. 
In order to test the designed conceptual model, a check of the presented research hypothesis was conducted which requires description of the researched variables. Technology and equipment equity was measured by 11 designed scales for its comprising variables. The impact of those variables on perceived value was tested. Perceived value, on the other hand, was measured based on questions about the price of the product and the maximum price the consumer would pay for the product. The mathematical difference between the two prices identified the purchase stimulus which was related to perceived value and, respectively, to its price competitiveness.

The converted data from the electronic survey allows for the execution of the steps in the testing of the formulated research hypothesis. By applying analysis of variance it has been determined that whether a given factor variable impacts significantly the variation of its related dependent variable. This allows us to consider the described method as appropriate for the purposes of the study. The procedure was carried out by means of ANOVA analysis allowing for the definition of the dependent and independent variables. The results are presented in Table 1. For the purpose of analysis, a statistical error type $1-\alpha=0.05$ has been allowed for.

Table 1 presents the testing of the base variables by means of analysis of variance.

Table 1

Testing of the Base Variables by Means of Analysis of Variance

\begin{tabular}{lccc}
\hline Base Variables of "Technology and Equipment Equity" & \multicolumn{2}{c}{ Analysis of Variance } & Result \\
\cline { 2 - 3 } & F-Empirical & Statistical Significance (Sig.) & \\
\hline Production Technology & 168.29 & 0.00 & Impacts \\
Raw Material & 2.73 & 0.03 & Impacts \\
Additives and Preservatives & 4.23 & 0.00 & Impacts \\
Short Expiration Period & 10.91 & 0.00 & Impacts \\
Glass Bottle & 8.14 & 0.00 & Impacts \\
Low in Carbon Dioxide & 3.11 & 0.01 & Impacts \\
High Alcohol Content & 10.60 & 0.00 & Impacts \\
Origin of Raw Material & 4.27 & 0.00 & Impacts \\
Origin of the Brewery & 5.86 & 0.00 & Impacts \\
Small Brewery & 13.75 & 0.00 & Impacts \\
Taste Diversity & 9.43 & 0.00 & Impacts \\
\hline
\end{tabular}

As shown in Table 1, the significance level of all tested correlations was less than the marginal error of $\alpha=0.05$. This means that the null hypothesis, which states that a certain factor variable does not impact the dependent variable, can be rejected and therefore, the alternative hypothesis can be accepted, which states that the factor variable has a significant statistical impact on the dependent variable. The testing of the studied correlation confirmed that the 11 variables forming technology and equipment equity had an impact on consumers' perceived value. Therefore, it can be concluded that technology and equipment equity positively impacts the perceived value of craft beer. Hence, by means of targeted actions for the formation of this value for users, we can influence price competitiveness and, respectively, the price levels of products.

\section{Discussion and Conclusion}

According to the results of the study it is reasonable to state that the base variables forming technology and equipment equity of craft beer are production technology, raw material, additives and preservatives, origin of raw materials, short expiration period, glass bottle, low 
in carbon dioxide, high alcohol content, origin of the brewery, small brewery, and taste diversity. The confirmed positive impact of technology and equipment equity on perceived value shows that the described variables can be recognized as benefits for craft beer consumers and we believe that they increase the value provided for craft beer consumers. This, on the other hand, leads to satisfied customers who remain loyal for a long time and buy more of the product regardless of its price levels. It must be noted that providing additional value to craft beer consumers allows for the increase of price levels without increasing the consumers' sensitivity to price. Thus, business organizations can have higher profit without the risk of losing their clients.

In relation to the presented results, we would like to focus the attention of manufacturer's performance in each of the displayed variables and to recommend taking actions to bring them in line with consumer needs and desires.

In conclusion, the designed methodology and results from the conducted research may serve as a basis for future studies which test the impact of the rest of the determinants of customer equity - brand equity, relationship equity and value equity - on the price levels of products. The study of these correlations could help and direct managers to implement successful price policies.

\section{References}

Agarwal, S., \& Teas, R. K. (2002). Cross-national applicability of a perceived quality model. Journal of Product \& Brand Management, 11(4/5), 213-236.

Auliap, S., Sukati, I., \& Sulaiman, Z. (2016). A review: Customer perceived value and its Dimension. Asian Journal of Social Sciences \& Management Studies, 3(2), 150-162.

Babin, B. J., Darden, W. R., \& Griffin, M. (1994). Work and/or fun: Measuring hedonic and utilitarian shopping value. Journal of Consumer Research, 20(4), 644-56.

Baker, R. (2006). Pricing on purpose: Creating and capturing value. Hoboken, NJ: John Wiley \& Sons.

Blattberg, R. C., \& Deighton, J. (1996). Manage marketing by the customer equity test. Harvard Business Review, 74(4), $136-144$.

Blattberg, R., Getz, G., \& Thomas, J. (2001). Customer equity: Building and managing relationships as valuable assets. Boston: Harvard Business School Publishing Corporation.

Brady, M. K., \& Robertson, C. J. (1999). An exploratory study of service value in the USA and Ecuador. International Journal of Industry Management, 10(5), 469-486.

Chang, T. Z., \& Wildt, A. R. (1994). Price, product information, and purchase intention: An empirical study. Journal of the Academy of Marketing Science Journal, 22(1), 16-27.

Dodds, W. B., Monroe, K. B., \& Grewal, D. (1991). The effects of price, brand and store information on buyers' product evaluation. Journal of Marketing Research, 28(3), 307-319.

Furtwengler, D. (2010). Pricing for profit: How to command higher prices for your products and services. America: AMACOM.

Hanssens, D. M., Rust, R. T., \& Srivastava, R. K. (2009). Marketing strategy and Wall Street: Nailing down marketing's impact. Journal of Marketing, 73(6), 115-118.

Hartline, M. D., \& Jones, K. C. (1996). Employee performance cues in a hotel service environment: Influence on perceived service quality, value, and word-of-mouth intentions. Journal of Business Research, 35(3), 207-215.

Holbrook, M. B. (1994). The nature of customer value: An axiology of services in the consumption experience. In R. Rust, \& R. L. Oliver (Eds.), Service quality: New directions in theory and practice (pp. 21-71). Thousand Oaks, CA: SAGE.

Holbrook, M. B. (1999). Introduction to consumer value. In M. B. Holbrook (Eds.), Consumer value: A framework for analysis and research. London: Routledge. 
Huber, F., Herrmann, A., \& Braunstein, C. (2000). Testing the metric equivalence of customer value: An empirical test across Germany and Denmark. Paper presented at Multicultural Marketing Conference, Academy of Marketing Science, Kowloon, Japan.

Ivanov, Y. (2016). Price aspects of "Craft" beer's competitiveness in Bulgaria, Izvestiya. Journal of Varna University of Economics, 60(1), 78-92.

Kerin, R. A., Jain, A., \& Howard, D. J. (1992). Store shopping experience and consumer price-quality-value perceptions. Journal of Retailing, 68(4), 376-397.

Kotler, P. (2005). According to Kotler: The world's foremost authority on marketing answers all your questions. New York, NY: AMACOM.

Lemon, K. N., Rust, R. T., \& Zeithaml, V. A. (2001). What drives customer equity? Marketing Management, 10(1), $20-25$.

Leone, R., Rao, V., Keller, K., Man Luo, A., McAlister, L., \& Srivastava, R. (2006). Linking brand equity to customer equity. Journal of Service Research, 9(2), 125-138.

Mattsson, J. (1991). Better business by the Abc of values. Lund: Student Literature.

Morris, M. H., \& Morris, G. (1990). Market-oriented pricing: Strategies for management. New York: Quorum Books.

Nagle, T. T., Hogan, J. E., \& Zale, J. (2011). The strategy and tactics of pricing: A guide to growing more profitably. Boston: Pearson.

Nunnally, J. C. (1967). Psychometric theory ( $1^{\text {st }}$ ed.). New York, NY: McGraw-Hill.

O'Cass, A. (2001). An exploratory assessment: Fashion clothing involvement's influence on the development of perceptions of product knowledge expertise and confidence. In P. M. Tidwell \& T. E. Muller (Eds.), Asia pacific advances in consumer research (pp. 288-95). Provo, UT: Association for Consumer Research.

Pavlova, D. (2015). Customer equity management: The new business philosophy. Trakia Journal of Sciences, 13(1), 331336.

Pavlova, D. (2016). Customer equity management of industrial organizations in Bulgaria (Unpublished doctoral dissertation). University of Economics, Varna, Bulgaria.

Prendergast G., \& Wong, C. (2003). Parental influence on the purchase of luxury brands of infant apparel: An exploratory study in Hong Kong. Journal of Consumer Marketing 20(2), 157-169.

Rust, R., Lemon, K., \& Zeithaml, V. (2004). Return on marketing: Using customer equity to focus marketing strategy. Journal of Marketing, 68, 109-127.

Sánchez-Fernández, R., \& Iniesta-Bonillo, M. A. (2007). The concept of perceived value: A systematic review of the research. Marketing Theory, 7(4), 427-451.

Sheth, J. N., Newman, B. I., \& Gross, B. L. (1991). Consumption values and market choices: Theory and applications. Cincinnati, OH: South-Western Publishing Co.

Sweeney, J. C., \& Soutar, G. N. (2001). Consumer perceived value: The development of a multiple item scale. Journal of Retailing, 77(2), 203-220.

Sweeny, J. C., Soutar, G. N., \& Johnson, L. W. (1999). The role of perceived risk in the quality-value relationship: A study in a retail environment. Journal of Retailing, 75(1), 77-105.

Vogel, V., Evanschitzky, H., \& Ramaseshan, B. (2008). Customer equity drivers and future sales. Journal of Marketing, 72(6), 98-108.

Williams, P., \& Soutar, G. N. (2000). Dimensions of customer value and the tourism experience: An exploratory study. Paper presented at Australian and New Zealand Marketing Academy Conference, 28 November-1 December.

Woodruff, R. B. (1997). Customer value: The next source for competitive advantage. Journal of the Academy of Marketing Science, 25(2), 139-153.

Zeithaml, V. A. (1988). Consumer perceptions of price, quality, and value: A means-end model and synthesis of evidence. Journal of Marketing 52(3), 2-22. 